\title{
PEMBENTUKAN KARAKTER KEWARGAAN MULTIKULTURAL DALAM \\ PROGRAM KURIKULER DI MADRASAH ALIYAH SE-DAERAH ISTIMEWA YOGYAKARTA
}

\author{
Samsuri dan Marzuki \\ Fakultas Ilmu Sosial Universitas Negeri Yogyakarta \\ E-mail: samsuri@uny.ac.id
}

\begin{abstract}
Abstrak: Penelitian bertujuan untuk mengidentifikasi sumber-sumber nilai-nilai karakter kewargaan multikultural yang menjadi basis nilai pembinaan karakter kewargaan multikultur dan menyajikan model pembinaan karakter kewargaan multikultur dalam program kurikuler berdasar identifikasi kebutuhan di Madrasah Aliyah di Daerah Istimewa Yogyakarta. Metode penelitian yang digunakan adalah studi dokumentasi, focus group disscussion bersama para guru dalam MGMP PKN MA se-Daerah Istimewa Yogyakarta, dan observasi pelaksanaan pembentukan karakter kewargaan multikultural di sekolah sampel. Guru yang terlibat berjumlah 30 orang dari 21 sekolah. Instrumen pengumpulan data berupa dokumentasi rencana pelaksanaan pembelajaran, panduan observasi, dan panduan FGD, sedang analisis data dilakukan dengan teknik deskripsi kualitatif. Hasil penelitian memaparkan pembentukan karakter kewargaan multikultural di MA dan upaya mengharmonikan identitas Islam dan kebangsaan di MA. Penguatan integrasi nilai-nilai Islam dan kebangsaan ke dalam wajah multikultural pendidikan Islam Indonesia modern perlu dielaborasi lebih lanjut.
\end{abstract}

Kata kunci: pendidikan karakter, kewargaan multikultural, kurikulum, madrasah aliyah, Islam

\section{CHARACTER BUILDING FOR MULTICULTURAL CITIZENSHIP WITHIN THE CURRICULAR PROGRAMS IN MADRASAH ALIYAH, YOGYAKARTA}

\begin{abstract}
This study was aimed to identify the sources for multicultural citizenship character values which became the basis for multicultural citizenship character building. This study also presented a model of multicultural citizenship character building in the curricular program based on the identification of the needs in Madrasah Aliyah in Yogyakarta. The study used the documentation study, a focus group discussion with teachers in the association of civic teachers of Madrasah Aliyah in Yogyakarta, and observations of the implementation of the multicultural citizenship character building in the sample school. There were 30 teachers from 21 schools involved. The instruments uesd were in the form of the lesson plans, observation guidelines, and focus group discussion guidelines. The data were analyzed using the qualitative descriptive analysis. The findings showed the multicultural citizenship character building in Madrasah Aliyah and the efforts to harmonize the Islamic and nationalism identities in Madrasah Aliyah. The integration of the Islamic and nationalism values into the modern Indonesian Islamic education needed to be elaborated further.
\end{abstract}

Keywords: character education, multicultural citizenship, curriculum, Madrasah Aliyah

\section{PENDAHULUAN}

Madrasah Aliyah sebagai salah satu jenjang pendidikan menengah atas dengan kekhasan keagamaan Islam merupakan bagian tidak terpisahkan dalam sistem pendidikan nasional di Indonesia. Keindonesiaan dan keislaman tersaji dengan baik selama ini dalam model pendidikan nasional di Madrasah Aliyah. Data Kementerian Agama (Ditjen Pendidikan Islam Kementerian Agama RI, 2014) sampai dengan tahun 2007/2008 menyebutkan sedikitnya ada 644 MA Negeri (MAN) dan 4.499 MA Swasta (MAS). Dari data itu, MA di Daerah Istimewa Yogyakarta berjumlah 37 sekolah meliputi 13 MA Negeri dan 24 MA 
swasta. MA tersebut tersebar di lima kabupaten dan kota, masing-masing sembilan di Kabupaten Bantul, lima di Kabupaten Gunung Kidul, empat di Kabupaten Kulon Progo, 11 di Kabupaten Sleman, dan lima di Kota Yogyakarta (Dinas Pendidikan DIY, 2010). Kenyataan tersebut di satu sisi membuktikan bahwa Indonesia meskipun bukan negara berbasis agama tertentu, dengan menjadikan Pancasila sebagai dasar negara, secara aktual memberikan afirmasi bidang pendidikan Islam bagi mayoritas penduduknya.

Indonesia sebagai negara yang memiliki kemajemukan atas dasar suku, agama, ras dan golongan, pada 2009 mengukuhkan konsepsi "Pilarpilar Kebangsaan" Indonesia atau lengkap dikenal dengan "Empat Pilar Kehidupan Berbangsa dan Bernegara" (Setjen MPR RI, 2012). Majelis Permusyawaratan Rakyat (MPR) Republik Indonesia semenjak periode 2009-2014 di bawah Ketua MPR Taufik Kiemas mempertegas Pancasila, UndangUndang Dasar Negara Republik Indonesia Tahun 1945, Negara Kesatuan Republik Indonesia, dan Bhinneka Tunggal Ika sebagai konten keempat pilar tersebut. Meskipun ada perdebatan tentang posisi Pancasila yang menjadi salah satu pilar, karena Pancasila merupakan dasar negara, namun MPR RI bersikukuh menjadilkan Pancasila sebagai salah satu dari keempat pilar berbangsa dan bernegara. Pilar-pilar tersebut dalam praktiknya oleh MPR disosialisasikan melalui sejumlah media televisi, surat kabar dan online. Selain itu, MPR juga melakukan kegiatan semacam lomba cerdas cermat (LCC) "Empat Pilar."

Relevansinya dengan artikel ini, bagaimanakah nilai-nilai karakter kewargaan multikultural dalam konsensus nasional (empat pilar) itu dikembangkan dalam lingkungan MA? Telah menjadi kesadaran publik bahwa MA secara kuantitatif seluruhnya homogen dalam hal identitas keagamaan Islam. Pertanyaan di atas patut diajukan mengingat kekhawatiran sikap dan perilaku eksklusif dan menegasikan keberadaan identitas masyarakat yang berbeda kini terus berkembang dan mengancam integrasi nasional. Penelitian Raihani (2012:585) menunjukkan bahwa keberadaan lempaga pendidikan Islam, seperti halnya sekolah-sekolah berbasis pesantren, menghadapi sorotan terutama media Barat, yang seolah tidak bisa menerima pengajaran nilai-nilai dan praktik demokrasi, penguatan masyarakat madani, dan penanaman nilai-nilai toleransi dan penghormatan terhadap keberagaman baik kultural maupun pemahamahan keagamaan.

Sejalan dengan Raihani, pentingnya kesadaran multikultural dibangun melalui lembagalembaga pendidikan khas keagamaan (Islam). Sebagaimana dibahas Pettalongi (2013:179) bahwa pendidikan multikultural diyakini dapat menjadi solusi nyata bagi konflik dan terjadinya disharmoni di dalam masyarakat untuk menciptakan kesadaran pluralitas agama dan budaya.

Untuk itu, artikel ini mengelaborasi kebutuhan pembentukan karakter kewargaan multikultural di MA, terutama di DIY, berdasarkan dokumen pilar-pilar kebangsaan yang dikembangkan oleh MPR. Selain itu, artikel ini mendeskripsikan pengalaman pembinaan karakter kewargaan multikultural di MA selama ini di DIY. Hal ini juga sejalan dengan Miller-Lane, Howard \& Halagao (2007) yang mengidentifikasi kompetensi kewargaan multikultural dapat dikembangkan melalui beragam kajian pembelajaran seperti social studies yang di dalamnya memuat topik pendidikan kewarganegaraan seperti di Amerika Serikat. Dengan begitu para guru diharapkan mampu menyiapkan siswa menghadapi kehidupan masyarakat global yaitu masyarakat multikultural.

Bagaimanakah mengukur keefektivan pembinaan karakter kewargaan multikultur di sekolah? Meminjam rumusan Character Education Partnership (2003) dan Lickona (1996) yang telah mengembangkan standar mutu pendidikan karakter, sedikitnya ada 11 prinsip yang harus dipenuhi untuk mengetahui keefektivan program pendidikan karakter. Kesebelas aspek itu ialah sebagai berikut.

1) Memromosikan inti nilai-nilai etis sebagai dasar karakter yang baik (nilai-nilai etis yang pokok dapat berasal dari ajaran agama, kearifan lokal, maupun falsafah bangsa).

2) Mengartikan "karakter" secara utuh termasuk pemikiran, perasaan dan perilaku.

3) Menggunakan pendekatan yang komprehensif, bertujuan dan proaktif untuk perkembangan karakter.

4) Menciptakan suatu kepedulian pada masyarakat kampus/sekolah.

5) Memberikan para peserta didik peluang untuk melakukan tindakan moral. 
6) Memasukkan kurikulum akademik yang bermakna dan menantang dengan menghormati semua peserta didik, mengembangkan kepribadiannya, dan membantu mereka berhasil.

7) Mendorong pengembangan motivasi diri peserta didik.

8) Melibatkan staf/karyawan kampus (sekolah) sebagai komunitas pembelajaran dan moral yang berbagi tanggungjawab untuk pendidikan karakter serta berupaya untuk mengikuti nilainilai inti yang sama yang memandu pendidikan para peserta didik.

9) Memupuk kepemimpinan moral dan dukungan jangka-panjang terhadap inisiatif pendidikan karakter.

10) Melibatkan keluarga dan anggota masyarakat sebagai mitra dalam upaya pembangunan karakter.

11) Menilai karakter kampus, fungsi staf kampus (sekolah) sebagai pendidik karakter, dan memperluas kesempatan para peserta didik untuk menampilkan karakter yang baik.

Dari kesebelas indikator pendidikan karakter yang efektif tersebut tampak bahwa, tanggung jawab pendidikan karakter tidak hanya terletak kepada peran sekolah, tetapi juga perlu melibatkan peran orang tua dan masyarakat. Di lingkungan sekolah pun, pendidikan karakter perlu didukung oleh kultur sekolah yang melibatkan segenap elemen utama seperti pimpinan sekolah, guru, karyawan dan iklim berkarakter mulia di antara sesama peserta didik. Dengan demikian sebelas prinsip itu menegaskan bahwa pendidikan karakter itu akan efektif jika: (1) dilakukan secara aktif, (2) untuk individu-individu, dan (3) demi masyarakat yang baik (Hoge, 2002:104).

Pada bagian lain, Baidhawy (2007) mengenalkan hasil kajiannya tentang pentingnya teologi multikultural, terutama di Indonesia. Dalam analisanya, Baidhawy menemukan bahwa identitas keagamaan Islam yang mayoritas dijumpai terutama di lembaga-lembaga pendidikan semacam madrasah aliyah, dapat menjadi tempat terbaik untuk menyemai harmoni melalui pendidikan agama berbasis teologi multikulturalis.

Sejalan dengan karakter masyarakat kewargaan yang kondusif untuk kehidupan politik demokrasi, ada beberapa penjelasan tentang karakter demokratis warga negara. Sejalan dengan Patrick (1999:45) dan Branson (1999), karakter kewarganegaraan dalam sistem demokrasi merupakan modal penting, terutama modal intelektual, yang patut dikembangkan dalam kehidupan demokrasi. Modal intelektual tersebut bertalian erat dengan keterlibatan warga dalam kehidupan publik dan kewargaan sebagai atribut warga negara yang baik, yakni seperti sikap toleransi politik, minat politik, dan efikasi politik. Dengan demikian dalam kehidupan bersama perlu dibangun karakter: menjadi anggota masyarakat yang independen, memenuhi tanggung jawab personal kewarganegaraan di bidang ekonomi dan politik, menghormati harkat dan martabat kemanusiaan tiap individu, berpartisipasi dalam urusan-urusan kewarganegaraan secara efektif dan bijaksana, serta, mengembangkan berfungsinya demokrasi konstitusional secara sehat.

Dari paparan latar belakang masalah di atas, fokus artikel ini adalah membahas pertanyaan-pertanyaan sebagai berikut. Pertama, apa sajakah sumber-sumber nilai-nilai karakter kewargaan multikultural yang menjadi basis nilai pembinaan karakter kewargaan multikultur di Madrasah Aliyah? Kedua, bagaimanakah model pembinaan karakter kewargaan multikultur dalam program kurikuler di Madrasah Aliyah (MA) di Daerah Istimewa Yogyakarta?

Penelitian ini menjelaskan dua tujuan. Pertama, mengidentifikasi sumber-sumber nilai-nilai karakter kewargaan multikultural yang menjadi basis nilai pembinaan karakter kewargaan multikultur di Madrasah Aliyah. Kedua, menyajikan model pembinaan karakter kewargaan multikultur dalam program kurikuler berdasar identifikasi kebutuhan di Madrasah Aliyah (MA) di Daerah Istimewa Yogyakarta.

\section{METODE}

Artikel ini disusun sebagai bagian laporan penelitian pengembangan tahun pertama pada tahun 2014. Penelitian dilaksanakan di Yogyakarta, meliputi observasi ke MA sampel dan Focus Group Disscusion (FGD) bersama guru-guru PKn dari MA Negeri dan Swasta se-DIY. Dari 37 MA negeri dan swasta, hanya 21 MAnegeri dan swasta yang ikut serta dalam penelitian, karena keterlibatan mereka dalam MGMP PKN MA DIY. 
Dalam penelitian ini, subjek penelitian meliputi para guru Pendidikan Kewarganegaraan Madrasah Aliyah se-Daerah Istimewa Yogyakarta yang menjalankan program kurikuler mata pelajaran Pendidikan Kewarganegaraan ((Kurikulum 2006) serta Pendidikan Pancasila dan Kewarganegaraan (Kurikulum 2013) di sekolah untuk mengimplementasikan pembinaan karakter kewargaan multikultural berbasis pilar-pilar kebangsaan. Jumlah guru yang terlibat dalam penelitian ini berjumlah 30 orang dari 21 sekolah. Instrumen pengumpul data berupa dokumentasi rencana pelaksanaan pembelajaran (RPP) semua guru anggota MGMP PKN MA DIY, panduan observasi, serta panduan FGD. Temuan penelitian disajikan dalam bentuk naratif dan deskripsi kualitatif.

\section{HASIL}

\section{Sumber Nilai Karakter Kewargaan Multikul- tural}

Nilai karakter kewargaan multikultural yang dikembangkan di MA DIY bersumber kepada nilai-nilai ajaran Islam dan nilai-nilai kebangsaan. Sumber nilai pertama merupakan konsekuensi logis dari keberadaan MA sebagai lembaga pendidikan formal berbasis (kekhasaan) keagamaan Islam. Nilai-nilai kebangsaan yang menjadi dasar pengembangan ini pun merupakan konsekuensi dari konteks kehidupan keberadaan pembentukan MA sebagai salah salah lembaga pendidikan formal yang tidak dapat dipisahkan dari sistem pendidikan nasional.

Nilai-nilai ajaran Islam menjadi sumber utama pengembangan nilai karakter siswa. MA sebagai bagian utama satuan pendidikan formal jenjang sekolah menengah atas dengan ciri khas keagamaan Islam dalam sistem pendidikan nasional merupakan produk sejarah dari hubungan antara Islam dan Negara sejak era kemerdekaan Indonesia. Di MA ini selain diajarkan ilmu pengetahuan tentang ajaran Islam yang berkaitan dengan keyakinan (iman), ibadah dan urusan hidup di dunia dan ukhrawi (kehidupan akhirat), juga diajarkan ilmu pengetahuan umum yang berkaitan langsung dengan kebutuhan hidup sehari-hari dalam kehidupan berbangsa dan bernegara.

Kurikulum MA memuat komposisi kajian ke-Islam-an baik sebagai keyakinan maupun sebagai keilmuan, dan kajian kurikuler pengetahuan umum yang diajarkan secara proporsional dalam struktur kurikulumnya. Dalam praktiknya, pengembangan kajian kurikuler di MA berpijak pada dua kaki. Pertama, sebagaimana diatur dalam Peraturan Pemerintah RI No. 55 Tahun 2007 tentang Pendidikan Agama dan Keagamaan maka kajian kurikuler selain pendidikan agama Islam, juga diajarkan secara kajian khusus tentang Akidah, Akhlak, ulumul Qur'an, Tafsir Hadith, Sejarah Kebudayaan Islam dan Bahasa Arab. Kedua, Kurikulum pendidikan umum di MA mengikuti ketentuan dalam Peraturan Menteri Pendidikan dan Kebudayaan. Pada Tahun Ajaran 2014/2015, di MA sudah menerapkan Kurikulum 2013 untuk kelas X, sedangkan untuk kelas XI dan XII masih menggunakan Kurikulum 2006.

Kedua macam program kurikuler tersebut menjadikan MA, sebagaimana Madrasah Ibtidaiyah di level sekolah dasar dan Madrasah Tsanawiyah di level sekolah menengah pertama, memiliki tugas ganda. Selain membekali siswa komptensi ilmu-ilmu keagamaan, MA juga membekali kompetensi ilmu-ilmu umum yang diperlukan sebagai bekal dalam kehidupan berbangsa dan bernegara.

Kondisi MA yang demikian menjadikannya cenderung homogen secara keagamaan, yakni seluruh komponen pendidik, tenaga pendidik dan siswa semua beragama Islam. Namun, dalam praktik keseharian pemahaman terhadap ajaran agama Islam itu sendiri tidaklah tunggal, bahkan memiliki keanekaan yang bersifat dinamis baik di bawah payung organisasi keagamaan maupun tradisi intelektual Islam.

Nilai-nilai ajaran Islam yang menghubungkan gagasan multikultural dengan kewargaan/ kebangsaan antara lain tampak dalam pernyataan Qur'an tentang penciptaan manusia yang bersukusuku dan berbangsa-bangsa, di mana yang membedakannya hanya kepada tingkat ketakwaan seseorang terhadap Allah Yang Maha Pengasih dan Penyayang. Di sisi lain, ajaran Islam tentang pentingnya hubungan antara sesama manusia dengan segenap keragaman latar belakang dalam aspek kehidupan di dunia adalah bagian utama peran seorang muslim sebagai khalifatullah fil ardl (pemimpin di muka bumi). Nilai-nilai ajaran Islam yang sering dikemukakan untuk menghar- 
gai perbedaan dan keragaman baik di lingkungan sesama Muslim maupun dengan masyarakat pemeluk agama lainnya terutama tampak dalam hal semangat toleransi beragama, karena prinsipnya "bagimu agamamu, dan bagiku (Islam) agamaku."

Pada bagian lain, nilai-nilai kebangsaan dan kenegaraan Indonesia yang dikembangkan guru dalam penelitian ini ialah dokumen MPR tentang "Empat Pilar Kehidupan Berbangsa dan Bernegara". Dokumen memuat kajian arti penting Pancasila, UUD Negara Republik Indonesia Tahun 1945, Bhinneka Tunggal Ika dan Negara Kesatuan Republik Indonesia. Dokumen ini menjadi rujukan formal materi pokok Pendidikan Pancasila dan Kewarganegaraan dalam Kurikulum 2013 oleh para guru PKn/PPKn. Di luar program kurikuler, guru-guru juga terlibat pembimbingan para siswanya dalam perlombaan "Empat Pilar" yang rutin dilaksanakan mulai tingkat Kota/Kabupaten hingga tingkat nasional. Bagi guru-guru MA se-DIY, sebelum Kurikulum 2013 dilaksanakan, sejak kebijakan "Empat Pilar" digulirkan MPR era 2009-2014 telah dikembangkan dalam mata pelajaran PKn di kelas X hingga XII.

Dari identifikasi nilai-nilai kebangsaan dan kenegaraan Indonesia, guru-guru PPKn/PKn MA se-DIY telah menerjemahkan materi-materi kewargaan multikultural sebagaimana dimuat dalam dokumen MPR tersebut sebagai berikut. Materi Pancasila meliputi nilai-nilai Ketuhanan, Kemanusiaan, Persatuan, Kerakyatan, dan Keadilan. Untuk materi Undang-Undang Dasar Negara Republik Indonesia Tahun 1945, meliputi topik Kesetaraan Hak dan Kewajiban setiap Warga Negara, Pengakuan dan Penghormatan setiap orang yang memiliki latar belakang berbeda, dan Kewajiban Negara melindungi setiap individu warga negara yang memiliki latar belakang berbeda. Perihal Bhinneka Tunggal Ika, membahas tentang kodrati Indonesia memiliki keanekaan namun tetap dalam satu bingkai ke-Indonesia-an. Sedangkan untuk nilai karakter dalam konsepsi Negara Kesatuan Republik Indonesia antara lain arti penting menjaga persatuan dan kesatuan serta keutuhan wilayah dan kedaulatan NKRI.

\section{Program Pembentukan Karakter Kewargaan Multikultural \\ Program Intra Kurikuler Mata Pelajaran Pendidikan Kewarganegaraan}

Kegiatan pembinaan kewargaan multikultural dilaksanakan sesuai pada materi yang terkait dalam pelajaran, dan dilakukan oleh gurunya masing-masing. Materi tersebut muncul secara eksplisit dalam pelajaran Pendidikan Kewarganegaraan dan Sosiologi. Dan secara implisit pada mata pelajaran lain, misalnya aqidah akhlak, sejarah, penjaskes, dan lain-lain. Pada bagian lain, Pada Tahun Ajaran 2014/2015 di Madrasah Aliyah secara nasional masih berlaku Kurikulum 2006 untuk kelas XI dan XII, sedangkan untuk Kelas X berlaku Kurikulum 2013.

Dalam penelitian ini, pilar-pilar kebangsaan yang menjadi inti karakter kewargaan multkultural di Madrasah Aliyah diajarkan sebagai materi pokok dalam mata pelajaran Pendidikan Pancasila dan Kewarganegaraan Kelas X Kurikulum 2013. Pilar-pilar kebangsaan dalam Mata Pelajaran Pendididikan Pancasila dan Kewarganegaraan Kelas X dijabarkan dengan mengikuti Kompetensi Dasar dalam Struktur Kurikulum 2013 dan Buku Siswa serta Buku Guru.

Mata Pelajaran Pendidikan Kewarganegaraan di Kelas XI dan XII tidak secara eksplisit membagi materi pelajarannya ke dalam empat pilar tersebut. Meskipun demikian guru-guru dalam MGMP PKn DIY mengelaborasi karakter kewargaan multikultur dari pilar-pilar kebangsaan berdasarkan kepada standar kompetensi (SK) dan kompetensi dasar Mata Pelajaran Pendidikan Kewarganegaraan Kurikulum 2006 untuk kelas XI dan XII.

Pilar-pilar kebangsaan yang menjadi materi pembinaan karakter kewargaan multikultural secara kurikuler di Kelas X dijabarkan mengikuti kompetensi dasar Mata Pelajaran Pendidikan Pancasila dan Kewarganegaraan seperti dimuat dalam Tabel 1. Dalam Tabel 1 tampak jelas bahwa komponen materi Mata Pelajaran Pendidikan Pancasila dan Kewarganegaraan terdiri atas empat materi pokok, yakni Pancasila, UUD Negara Republik Indonesia Tahun 1945, Bhinneka Tunggal Ika dan Negara Kesatuan Republik Indonesia. Materi ini sejalan dan mengacu kepada keputusan MPR RI periode 2009-2014 untuk menjadi keempat materi 
yang disebut dengan "Pilar-pilar Kebangsaan dan Kenegaraan Indonesia."

Keempat materi pokok itu disebar pencapaiannya ke dalam empat aspek kompetensi inti dan kompetensi dasar, meliputi aspek sikap spiritual, sikap sosial, pengetahuan dan keterampilan. Di Kelas X, aspek penting kompetensi dasar pengetahuan dan keterampilan membahas tentang (1) kasus-kasus pelanggaran hak asasi manusia, (2) pokok pikiran yang terkandung dalam Pembukaan Undang-Undang Dasar Negara Republik Indonesia Tahun 1945, serta bentuk dan kedaulatan Negara, serta hubungan struktural dan fungsional pemerintahan pusat dan daerah menurut UndangUndang Dasar Negara Republik Indonesia Tahun 1945, (3) sistem hukum dan peradilan nasional dalam lingkup NKRI, serta kasus pelanggaran hak dan pengingkaran kewajiban sebagai warga negara, (5) indikator ancaman terhadap negara dalam membangun integrasi nasional dengan bingkai Bhinneka Tunggal Ika, serta kesadaran berbangsa dan bernegara dari konteks sejarah dan geopolitik Indonesia.

Kesadaran multikultural peserta didik sebagai warga negara yang dimuat dari komponen kompetensi dan materi Mata Pelajaran Pendidikan Pancasila dan Kewarganegaraan tersebut yakni pertama, pentingnya menghormati hak-hak asasi manusia setiap orang tanpa membeda-bedakan suku, agama, ras, budaya dan gender sebagaimana dikehendaki dari nilai-nilai dasar Pancasila. Selain itu, kedua, keanekaan bangsa Indonesia menjadi kekuatan yang mengikat pencapaian tujuan kemerdekaan dan terbentuknya Negara Kesatuan Republik Indonesia dalam konstitusi (UUD NRI Tahun 1945), yang dalam penyelenggaraan pemerintahannya memiliki hubungan struktural dan fungsional antara pemerintah pusat dan daerah. Ketiga, integrasi nasional dari sifat keanekaan bangsa dan pembentukan negara serta kesadaran sejarah dan geopolitik Indonesia itu diperlukan dalam menghadapi setiap ancaman nasional terhadap keberadaan NKRI.

Materi pokok di Kelas XI dan XII tidak secara eksplisit pengelompokannya ke dalam empat pilar-pilar kehidupan berbangsa dan bernegara seperti dimaksudkan dalam Kurikulum 2013 pada Kelas X. Namun, apabila dicermati secara rinci dalam materi pokoknya dalam komponen kom- petensi dasarnya akan tergambar empat pilar itu. Adapun karakter kewargaan multikultur sangat besar peluangnya dikembangkan dari materimateri seperti budaya politik dan demokrasi, serta karakter masyarakat madani yang memandang penting sikap rekognisi dan respek terhadap setiap kebhinnekaan hidup bermasyarakat, berbangsa dan bernegara.

Pembentukan karakter kewargaan secara tegas disajikan di kelas XI Semester Gasal ketika menyajikan topik Budaya Politik dan Budaya Demokrasi (Kurikulum 2006). MA di wilayah Kabupaten Bantul sebagaimana juga jenjang SMA lainnya, bekerjasama dengan Komisi Pemilihan Umum Kabupaten Bantul, menyelenggarakan Pemilihan Umum OSIS (PEMILOS) untuk memilih pengurus OSIS. Pada saat penelitian berlangsung, baru diadakan persiapan-persiapan Pemilos untuk calon pengurus baru OSIS di MA se-Kabupaten Bantul. Kegiatan Pemilos terutama saat pemberian suara meniru proses pemungutan suara pemilu nasional dan pemilu langsung kepala daerah (Pilkada). Pemilos ini selain mengajarkan sistem demokrasi langsung, dan partisipasi siswa dalam OSIS, juga diajarkan nilai-nilai menghormati dan menghargai perbedaan dan keragaman aspirasi setiap siswa.

\section{Program Kokurikuler}

Program ko-kurikuler dalam pembinaan karakter kewargaan multikultur dimaknai sebagai serangkaian aktivitas peserta didik yang berkaitan langsung dengan tujuan kurikuler Pendidikan Kewarganegaran Kelas XI dan XII serta Pendidikan Pancasila dan Kewarganegaraan di Kelas X. Sebagian besar program ko-kurikuler yang teridentifikasi telah dilakukan oleh siswa Kelas XI dan XII, sedangkan untuk Kelas X yang sudah terlaksana ialah berkaitan dengan kegiatan upacara bendera dan kegiatan kerohanian.

Program kurikuler yang telah dijalankan antara lain berupa kewajiban setiap siswa atau kelompok kelas untuk melakukan aktivitas yang berhubungan langsung maupun tidak langsung dengan upaya pembinaan karakter kewargaan multikultur. Program tersebut meliputi kegiatan sebagai petugas upacara bendera secara bergiliran; kesempatan menjadi petugas Pasukan Pengibar Bendera (Paskibra); mengikuti lomba-lomba, 
misalnya : Lomba Cerdas Cermat (LCC) "Empat Pilar MPR", LCC Pendidikan Kewarganegaraan Universitas Negeri Yogyakarta, Lomba Debat, Lomba Peleton Inti (tonti); Mengikuti kegiatan yang dilaksanakan oleh pihak lain, misalnya Kemah Kerukunan antar Umat Beragama, yang dilaksanakan oleh Kantor Wilayah Kementerian Agama DIY, dan lain-lain. Semua program itu ada yang terencana namun ada pula yang dilakukan secara insidental.

\section{Program Ekstrakurikuler}

Program pembinaan karakter kewargaan multikultur di bidang ekstra kurikuler yang diklaim dilakukan oleh sejumlah MA DIY antara lain kegiatan Pramuka, Peleton Inti (Tonti), Palang Merah Remaja (PMR), Civic Club, English Club, Javanese Club dan olahraga futsal. Program-program ekstra-kurikuler tersebut ada yang berkaitan langsung dengan mata pelajaran $\mathrm{PKn} / \mathrm{PPKn}$, tapi ada juga yang sama sekali tidak berhubungan langsung. Namun, dalam praktiknya program ekstra-kurikuler diselengarakan untuk menyalurkan minat dan bakat serta menanamkan semangat kebangsaan (Pramuka), kemampuan pemecahan masalah, dan pelestarian budaya.

Upaya pembinaan karakter kewargaan multikultural di MA yang teridentifikasi di DIY, belum seluruhnya menampakkan keberhasilan. Ada sejumlah kendala berkaitan dengan pemahaman multikulturalis di antara komponen sekolah dan siswa, juga dari masyarakat sekitar itu sendiri.

Salah satu guru menyadari bahwa MA dipandang masyarakat masih bersifat eksklusif pengajarannya, selain karena latarbelakang siswa semua beragama Islam, juga ada pemikiran bahwa MA hanya mengajarkan soal-soal keagamaan belaka. Konsekuensinya, siswa yang tidak beragama Islam tidak mungkin dimasukkan ke MA oleh orangtuanya, tetapi akan dipilihkan sekolah-sekolah umum negeri maupun swasta. Secara internal, MA belum siap memperkenalkan secara utuh keberadaan ajaran-ajaran agama di luar Islam, terutama di perpustakaannya, yang tidak mengenalkan kitab agama selain Islam, seperti Taurat, Zabur dan Injil, atau contoh pakaian kebesaran bila pemimpin agama lain memimpin acara keagamaan terutama agama yang diakui di Indonesia.
Pada bagian lain, guru juga menyadari bahwa stakeholder sekolah belum sepenuhnya tumbuh kesadaran terhadap urgensi pembinaan karakter itu sebagai tanggungjawab bersama, bukan hanya guru agama, PKn atau BK semata. Selama ini pembinaan karakter hanya dititikberatkan pada kewajiban guru-guru tertentu, seperti guru agama, PKn atau BK. Kajian tentang pembinaan karakter kewargaan multikultural berbasis pilar-pilar kebangsaan di MA barangkali baru kali pertama dilakukan. Untuk itu, bukan hal mudah untuk menilai apakah proses dan hasil pembinaan karakternya sudah berhasil atau sesuai dengan kaidah yang diharapkan ataukah perlu ditindaklanjuti dengan program tindakan/intervensi.

Karakter kewargaan multikultural yang dibangun di sekolah khas keagamaan Islam sulit diidentifikasi karena belum ada standard penilaian atau instrumentasi yang baku untuk menakarnya. Hanya saja, secara empirik pembinaan karakter secara umum di MA berdasarkan kategori keefektifan pendidikan karakter menurut rumusan Character Education Partnership (2003), hampir seluruh komponen terpenuhi. Meski demikian, pelibatan stakeholder MA untuk dimensi karakter kewargaan multikultural perlu dikaji lebih dalam.

Penekanan kepada program kurikuler Mata Pelajaran Pendidikan Kewarganegaraan/ Pendidikan Pancasila dan Kewarganegaraan sesungguhnya meyakinkan banyak pihak bahwa tuntutan pembentukan karakter warga negara yang baik yang toleran dan positif terhadap keragaman, secara langsung diajarkan oleh mata pelajaran ini. Sungguh pun dalam pelajaran Agama diajarkan sikap tasamuh (toleran) terhadap orang yang berbeda-beda afiliasi bahkan keyakinan agamanya pun, namun pesan kuat pembinaan karakter kewargaan multikultural diarahkan kepada mata pelajaran PKn/PPKn.

Pilihan terhadap "pilar-pilar kebangsaan dan kenegaraan" sebagaimana dimaksudkan oleh MPR Periode 2009-2014, sebagai core matter dan core values dari pembinaan karakter kewargaan multikultur merupakan gayung bersambut dengan kebijakan program kurikuler PKn dan PPKn, terutama Kurikulum 2013. Materi pokok PPKn Kurikulum 2013 menjadi bagian penting nilainilai utama yang harus dirujuk dalam pembinaan karakter kewargaan multikultur. 
Dari hasil observasi dan FGD terhadap guru-guru anggota MGMP PKN DIY, disadari betul bahwa pembinaan karakter kewargaan multikultur di sekolah khas keagamaan Islam seperti MA masih terbatas dan lebih banyak menitikberatkan kepada program kurikuler di kelas. Ini disadari karena tuntutan pembentukan karakter siswa secara umum masih bertumpu kepada mata pelajaran pembentukan kepribadian seperti pendidikan agama dan PPKn/PKn. Dengan demikian keefektifan pembinaan karakter kewargaan multikultur sebagai bagian grand design pendidikan karakter di sekolah masih perlu diteruskan kajian mendalamnya dalam penelitian berikutnya.

Pada bagian lain, "kesadaran" tentang eksklusivitas identitas sekolah berbasis kekhasan agama Islam oleh para guru tidak menjadi halangan untuk menanamkan dan menumbuhkan karakter kewargaan multikultur siswa dan elemen sekolah lainnya. Hanya saja, komitmen multikulturalis dari pimpinan sekolah, guru dan tenaga kependidikan lainnya, orang tua siswa, masyarakat sekitar dan siswa itu sendiri merupakan modal besar yang harus dihadirkan untuk membangun sikap dan perilaku multikulturalis di sekolah semacam MA.

\section{SIMPULAN}

Dari paparan di muka dapat dinyatakan bahwa bahwa pembinaan karakter kewargaan multikultural dalam program kurikuler di MA tampak ditekankan dalam mata pelajaran Pendidikan Kewarganegaraan (Kurikulum 2006) serta Pendidikan Pancasila dan Kewarganegaraan (Kurikulum 2013). Sumber-sumber program kurikuler untuk pembinaan karakter kewargaan multikultural dilakukan dengan pengintegrasian nilai-nilai keislaman sebagai ciri MA dan nilainilai kebangsaan sebagaimana dimuat dalam pilar-pilar kebangsaan Indonesia secara eksplisit dalam mata pelajaran Pendidikan Kewarganegaraan (Kurikulum 2006) serta Pendidikan Pancasila dan Kewarganegaraan (Kurikulum 2013).

\section{SARAN}

Keefektivan pembentukan karakter kewargaaan multikultural di MA, selain bertumpu kepada mata pelajaran utama seperti Pendidikan Kewarganegaraan (Kurikulum 2006) serta Pen- didikan Pancasila dan Kewarganegaraan (Kurikulum 2013), juga perlu disokong oleh kajian mata pelajaran lainnya dalam struktur kurikulum persekolahan. Selain itu, kultur madrasah yang kondusif untuk penumbuhan karakter kewargaan multikultural sangat banyak dipengaruhi oleh keteladanan mulai dari unsur pemimpin madrasah, guru, komite sekolah dan kegiatan kesiswaan. Dengan demikian, sinergitas antar unsur komponen madrasah dalam pembentukan karakter kewargaan multikultural menjadi faktor penting lainnya.

\section{UCAPAN TERIMA KASIH}

Terima kasih disampaikan kepada seluruh pihak yang membantu terlaksanakannya penelitian ini terutama Dikti yang telah membiayai lewat skim Hibah Bersaing, para kolega, dan guru MA di DIY. Mudah-mudahan kesemuanya itu diperhitungkan Allah sebagai amal ibadah.

\section{DAFTAR PUSTAKA}

Baidhawy, Zakiyuddin. 2007. "Building Harmony and Peace Through Multiculturalist Theology Based Religious Education: an Alternative for Contemporary Indonesia," British Journal of Religious Education, 29 (1), hlm. 15-30.

Branson, M.S. 1999. "Dasar-dasar Civic Education," dalam Margaret S. Branson, et al. Belajar Civic Education dari Amerika. Terj. Syafruddin, M. Nasir Alimi, dan M. Nur Khoiron. Yogyakarta: LKiS, hlm.1-88.

Character Education Partnership. 2003. Character Education Quality Standards. Washington: Character Education Partnership

Dinas Pendidikan Provinsi DIY. 2010. Data Madrasah Aliyah. http://www.pendidikan-diy. go.id/file/alamat_sekolah/SMA_DIY.xlsx. Diakses pada 10 Oktober 2014.

Ditjen Pendidikan Islam Kementerian Agama RI. 2014. Direktori Madrasah Aliyah Tahun 2007/2008, http://pendis.kemenag.go.id/ index.php? $\mathrm{a}=\operatorname{artikel} \& \mathrm{id} 2=$ statma2009\#. VHfI4cl-Y0c. Diakses pada 10 Oktober 2014. 
Hoge, J. D. 2002 "Character Education, Citizenship Education, and the Social Studies," The Social Studies, 93(3), hlm. 103-108.

Lickona, T. 1996. "Eleven Principles of Effective Character Education." Journal of Moral Education, 25(1), hlm. 93-100.

Miller-Lane, J., Howard, T. C., \& Halagao, P. E. 2007. "Civic Multicultural Competence: Searching for Common Ground in democratic Education," Theory \& Research in Social Education, 35(4), hlm. 551-573.

Patrick, J. J. 1999. "Education for Constructive Engagement of Citizens in Democratic Civil Society and Government," dalam Charles F. Bahmueller dan John J. Patrick (eds.), Principles and Practice of Education for Democratic Citizenship, International Perspectives and Projects. Bloomington, IN.: ERIC Clearinghouse for Social Studies/ Social Science Education, Hlm. 41-60.
Peraturan Menteri Pendidikan dan Kebudayaan RI No. 69 Tahun 2013. Lampiran I b.

Peraturan Menteri Pendidikan Nasional RI No. 22 Tahun 2006. Lampiran

Peraturan Pemerintah RI No. 55 Tahun 2007 tentang Pendidikan Agama dan Keagamaan

Pettalongi, Sagaf S. 2013. "Islam dan Pendidikan Humanis dalam Resolusi Konflik Sosial." Cakrawala Pendidikan, XXXII (2), hlm.172-182.

Raihani. 2012. "Report on Multicultural Education in Pesantren." Compare, 42 (4). hlm. 585-605

Setjen MPR RI. 2012. Empat Pilar Kehidupan Berbangsa dan Bernegara. Jakarta: Setjen MPR RI. 